\title{
Jasmonic Acid, but not Salicylic Acid, Improves PLB Formation of Hybrid Cymbidium
}

\section{Jaime A. Teixeira da Silva}

Faculty of Agriculture and Graduate School of Agriculture, Kagawa University, Miki-cho, Kagawa, 761-0795, Japan

Key words: Protocorm-like bodies, Jasmonic acid, Salicylic acid, Teixeira Cymbidium medium

Protocorm-like bodies (PLBs), equivalent to somatic embryos in orchids, are the most stable form of clonal propagation of orchids in vitro. PLBs or PLB thin cell layers of hybrid Cymbidium Twilight Moon 'Day Light', could form more PLBs when added to Teixeira Cymbidium (TC) medium without plant growth regulators, but supplemented with $1-2 \mathrm{mg} / \mathrm{l}$ of jasmonic acid. Salicylic acid decreased the number of PLBs. This protocol constitutes a simple means to mass produce PLBs for commercial hybrid Cymbidium and points towards jasmonates as being an important developmental elicitor for orchids.

Jasmonic acid (JA) and salicylic acid (SA) are two elicitors associated with stress-related events in plants, formed in response to biotic and abiotic stressors. Plant development is often related to ethylene and closely related methyl jasmonate (MeJA) pathways, which are often interlinked (Saniewski et al. 2002). MeJA, as with JA and SA, are related to plant defense (Almagro et al. 2009). MeJA is usually associated with growth inhibition (for example Medicago sativa somatic embryogenesis; Ruduś et al. 2006) rather than growth promotion and thus its application to plant tissue culture - in terms of developmental studies remains limited, although it serves as an elicitor for secondary metabolite production in vitro (Koo and Howe 2009). Thin cell layers or TCLs, which are important cellular developmental blocks in plant tissue culture (Teixeira da Silva 2013), were used to enhance adventitious root production in tobacco after exposure to MeJA (Fattorini et al. 2009) although, interestingly, it disrupted TCLderived shoot formation, also in tobacco, by over-inducing mitotic activity and cell expansion (Capitani et al. 2005). MeJA also reduced microrhizome biomass in turmeric cultures (Cousins and Adelberg 2008). MeJA at $1 \mu \mathrm{M}$ stimulated protocorm-like body (PLB) formation (from shoots) and shoot formation in epiphytic Cymbidium eburneum and in terrestrial Cymbidum kanran Makino (Shimasaki et al. 2003) while it stimulated, when applied at $1.0 \mathrm{mg} / \mathrm{l}$, PLB 
formation from half-moon PLBs and PLB TCLs in a hybrid Cymbidium (Teixeira da Silva 2012). In vitro Lilium bulb formation was enhanced in the presence of MeJA (Jásik and de Klerk 2006), as was bulb formation in garlic (Ravnikar et al. 1993) while in vitro tuberization in potato was enhanced by MeJA or JA (0.2 - 2.0 $\mathrm{mg} / \mathrm{l})$, usually in the presence of a cytokinin, 6-benzyladenine (Sarkar et al. 2006). The latter batch of results suggests that jasmonates enhance storage organ formation in tuberous crops.

Even though in vitro protocols for the induction and development of PLBs of hybrid Cymbidium are well established, no study exists yet on the use of and effect of JA and SA in vitro on any orchid. Thus, using a newly developed ideal Cymbidium PLB regeneration medium, termed Teixeira Cymbidium (TC) medium (Teixeira da Silva 2012), the effect of JA and SA on PLB formation was assessed ultimately with the objective of increasing PLB formation.

PLBs of hybrid Cymbidium Twilight Moon 'Day Light' (Bio-U, Japan) originally developed spontaneously from shoot-tip culture on Vacin and Went (1949) agar medium without plant growth regulators (PGRs), were induced and subcultured (PLB induction and proliferation medium or VW months on TC medium (Teixeira da Silva 2012), which contains unique levels of macro- and micronutrients, and was supplemented with two plant growth regulators $(0.1 \mathrm{mg} / \mathrm{l} \mathrm{NAA}$ and $0.1 \mathrm{mg} / \mathrm{Kn}), 2.0 \mathrm{~g} / 1$ tryptone and $20.0 \mathrm{~g} / \mathrm{l}$ sucrose, and solidified with $8 \mathrm{~g} / \mathrm{l}$ Bacto agar (Difco Labs., USA), according to procedures and advice outlined by Teixeira da Silva et al. (2005) and Teixeira da Silva and Tanaka (2006). All media were adjusted to $\mathrm{pH} 5.3$ with $1 \mathrm{~N} \mathrm{NaOH}$ or $\mathrm{HCl}$ prior to autoclaving at $100 \mathrm{KPa}$ for $17 \mathrm{~min}$. Cultures were kept on $40 \mathrm{ml}$ medium in 100-ml Erlenmeyer flasks, double-capped with aluminium foil, at $25^{\circ} \mathrm{C}$, under a $16 \mathrm{hr}$ photoperiod with a light intensity of $45 \mu \mathrm{mol} / \mathrm{m}^{2} / \mathrm{s}$ provided by plant growth fluorescent lamps (Homo Lux, Matsushita Electric Industrial Co., Japan). Longitudinally bisected PLB (3 - $4 \mathrm{~mm}$ in diameter) segments, 10 per flask, were used as explants for PLB induction and proliferation and for all experiments. Culture conditions and media followed the recommendations previously established for medium formulation (Teixeira da Silva et al. 2005), biotic (Teixeira da Silva et al. 2006b) and abiotic factors (Teixeira da Silva et al. 2006a) for PLB induction, formation and proliferation.

Half-moon PLBs and PLB thin cell layers (TCLs) were cultured on PGR-free TC or PGR-containing TC medium in the presence of $1,2,4$, or $8 \mathrm{mg} / 1 \mathrm{JA}$ or SA, applied separately. The control contained no PGRs and no JA or SA. Solutions were made fresh and were filtered prior to the addition to TC medium. 
All chemicals and reagents were of the highest analytical grade available and were purchased from either Sigma-Aldrich (St. Louis, USA), Wako (Osaka, Japan) or Nacalai Tesque (Kyoto, Japan), unless specified otherwise.

The number of PLBs formed per PLB segment or PLB TCL was measured. All measurements were made after 45 days in culture (by exceeding 45 days, and if left on the same medium, PLBs induce shoots spontaneously). The occurrence of hyperhydricity, scored with the naked eye, was also noted at 45 days.

Table 1. Effect of methyl jasmonate on PLB formation from half-PLB culture of hybrid Cymbidium Twilight Moon 'Day Light'.

\begin{tabular}{llccc}
\hline $\begin{array}{l}\text { Medium } \\
\text { composition }\end{array}$ & $\begin{array}{l}\text { Conc. } \\
(\mathrm{mg} / \mathrm{l})\end{array}$ & $\begin{array}{c}\text { \% of explants } \\
\text { forming neo- } \\
\text { PLBs }\end{array}$ & $\begin{array}{c}\text { No. of PLBs } \\
\text { per explant }\end{array}$ & $\begin{array}{c}\text { Fresh wt. (mg) of } \\
\text { PLB explant + neo- } \\
\text { PLBs }\end{array}$ \\
\hline TC (Control) & & $100 \mathrm{a}$ & $8.3 \mathrm{a}$ & $526 \mathrm{a}$ \\
PGR-free TC & $100 \mathrm{a}$ & $1.2 \mathrm{~d}$ & $321 \mathrm{~b}$ \\
Half-moon PLBs on: & 1 & $100 \mathrm{a}$ & $8.5 \mathrm{a}$ & $531 \mathrm{a}$ \\
PGR-free TC+ JA & 2 & $100 \mathrm{a}$ & $4.1 \mathrm{c}$ & $302 \mathrm{~b}$ \\
& 4 & $71 \mathrm{~b}$ & $2.2 \mathrm{~cd}$ & $146 \mathrm{~cd}$ \\
PLB TCLs on: & 8 & $35 \mathrm{c}$ & $0.6 \mathrm{de}$ & $101 \mathrm{~d}$ \\
PGR-free TC+ JA & 2 & $100 \mathrm{a}$ & $3.8 \mathrm{c}$ & $268 \mathrm{c}$ \\
& 4 & $100 \mathrm{a}$ & $1.2 \mathrm{~d}$ & $281 \mathrm{c}$ \\
Half-moon PLBs on: & 1 & $69 \mathrm{~b}$ & $0.3 \mathrm{de}$ & $118 \mathrm{~d}$ \\
PGR-free TC+SA & 2 & $51 \mathrm{bc}$ & $0.13 \mathrm{e}$ & $42 \mathrm{~d}$ \\
& 4 & $100 \mathrm{a}$ & $6.6 \mathrm{~b}$ & $518 \mathrm{a}$ \\
& $61 \mathrm{bc}$ & $2.3 \mathrm{~cd}$ & $226 \mathrm{c}$ \\
PLB TCLs on: & 1 & $24 \mathrm{c}$ & $1.1 \mathrm{~d}$ & $109 \mathrm{~d}$ \\
PGR-free TC+SA & 2 & $8 \mathrm{~d}$ & $0 \mathrm{e}$ & $62 \mathrm{de}$ \\
& 4 & $100 \mathrm{a}$ & $3.6 \mathrm{c}$ & $241 \mathrm{c}$ \\
& 8 & $54 \mathrm{bc}$ & $1.0 \mathrm{~d}$ & $160 \mathrm{~cd}$ \\
& $16 \mathrm{~cd}$ & $0 \mathrm{e}$ & $98 \mathrm{~d}$ \\
& $3 \mathrm{~d}$ & $0 \mathrm{e}$ & $20 \mathrm{e}$ \\
\hline
\end{tabular}

Mean values followed by the same letter in the same column are not significantly different based on DMRT $(p=0.05)$. See text for media constituents. $n=90$ (9 Petri dishes $\times 10$ for each treatment). JA, jasmonic acid; SA, salicylic acid; TC, Teixeira Cymbidium medium, includes $0.1 \mathrm{mg} / 1 \mathrm{NAA}$ and $0.1 \mathrm{mg} / \mathrm{Kn}, 2 \mathrm{~g} / \mathrm{l}$ tryptone and $20 \mathrm{~g} / \mathrm{l}$ sucrose (see reference for modified micro- and macro-nutrients); TCL, thin cell layer.

Experiments were organized according to a RCBD with three blocks of 10 replicates per treatment (i.e., each medium). All experiments were repeated in triplicate ( $\mathrm{n}=90$, total sample size per treatment). Data were subjected to ANOVA with mean separation by DMRT using SAS ${ }^{\circledR}$ vers. 6.12 (SAS Institute, Cary, NC, USA). Significant differences between means were assumed at $\mathrm{p} \leq$ 0.05 . 
Since PLBs and somatic embryos are synonymous in orchids (Teixeira da Silva and Tanaka 2006), this protocol, using half-moon PLBs or PLB TCLs, is a means of mass producing PLBs substituting conventional PGRs, which is essential for bioreactor studies and other aspects requiring orchid biotechnology (Not published). In this study, JA was able to form significantly more PLBs than optimized TC medium (Table 1; Fig. 1A, B), while SA inhibited PLB formation (Fig. 1C). Jasmonates are a widely distributed group of PGRs in the plant kingdom (Ulloa et al. 2002) and JA owes its growth-promotive activity due to an
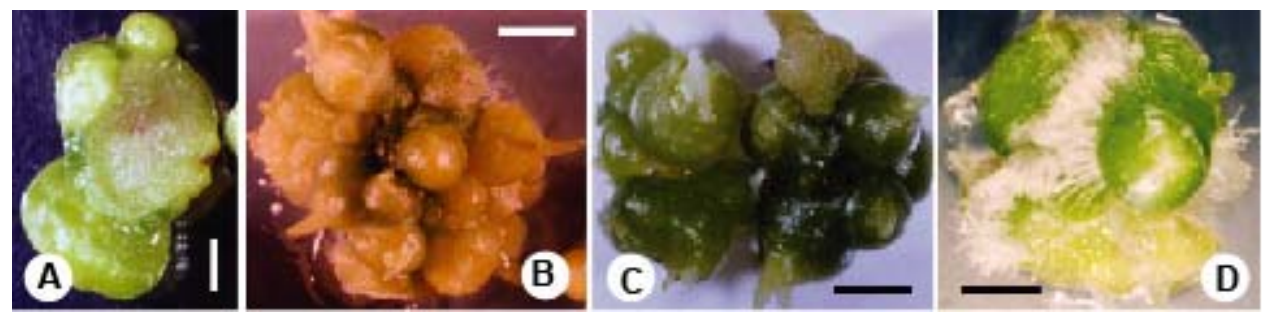

Fig 1. PLB induction from PLB TCLs (A) or half-moon PLBs (B) on Teixeira Cymbidium medium (TС рев) with PGRs (0.1 mg/l NAA + $0.1 \mathrm{mg} / \mathrm{Kn})$. PLB formation on TCprв without plant growth regulators but supplemented with $1.0 \mathrm{mg} / \mathrm{l}$ jasmonic acid (C) or salicylic acid (D). Bars = $0.5 \mathrm{~mm}(\mathrm{~A}, \mathrm{D}), 2.5 \mathrm{~mm}(\mathrm{~B}), 1 \mathrm{~mm}(\mathrm{C})$.

increase in cell division and expansion (Takahashi et al. 1994). Interestingly, TCLs, which are more sensitive developmental barometers than conventional explants, appeared to be more sensitive to SA than conventional half-moon explants (Table 1). MeJA is the volatile derivative of JA (Schaller et al. 2005), and thus it would be expected that the response of one would mirror the response of the other. Interestingly, at a high concentration of MeJA, total sugar accumulation (but not starch) in potato tubers was enhanced only when high levels of a cytokinin, 6-benzyladenine, were used, suggesting the synergistic effect of jasmonates and cytokinins (Sarkar et al. 2006). Cabbage (Brassica oleracea) shoot and root parameters were promoted in the presence of 2 - $50 \mathrm{nM} \mathrm{JA}$, but inhibited at much higher concentrations, 1250 - $6000 \mathrm{nM}$ (Toro et al. 2003).

\section{Acknowledgement}

The author thanks Prof. Michio Tanaka for research support.

\section{References}

Almagro L, Gómez Ros LV, Belchi-Navarro S, Bru R, Ros Barceló A and Pedreño MA (2009) Class III peroxidases in plant defence reactions. J. Exp. Bot. 60: 377-390. 
Capitani F, Biondi S, Falasca G, Ziosi V, Balestrazzi A, Carbonera D, Torrigiani P and Altamura MM (2005) Methyl jasmonate disrupts shoot formation in tobacco thin cell layers by over-inducing mitotic activity and cell expansion. Planta 220: 507-519.

Cousins MM and Adelberg JW (2008) Short-term and long-term time course studies of turmeric (Curcuma longa L.) microrhizome development in vitro. Plant Cell, Tissue Organ Cult. 93: 283-293.

Fattorini L, Falasca G, Kevers C, Rocca LM, Zadra C and Altamura MM (2009) Adventitious rooting is enhanced by methyl jasmonate in tobacco thin cell layers. Planta 231: 155-168.

Jásik J and de Klerk JG (2006) Effect of methyl jasmonate on morphology and dormancy development in lily bulblets regenerated in vitro. J. Plant Growth Reg. 25: 45-51.

Koo AJK and Howe GA (2009) The wound hormone jasmonate. Phytochemistry 70: 15711580.

Ravnikar M, Žel J, Plaper I and Špacapan A (1993) Jasmonic acid stimulates shoot and bulb formation of garlic in vitro. J. Plant Growth Reg. 12: 73-77.

Ruduś I, Kępczyńska E and Kępczyński J (2006) Comparative efficacy of abscisic acid and methyl jasmonate for indirect somatic embryogenesis in Medicago sativa L. Plant Growth Reg. 48: 1-11.

Saniewski M, Ueda J and Miyamoto K (2002) Relationships between jasmonates and auxin in regulation of some physiological processes in higher plants. Acta Physiol. Plant 24: 211-220.

Sarkar D, Pandey SK and Sharma S (2006) Cytokinins antagonize the jasmonates action on the regulation of potato (Solanum tuberosum) tuber formation in vitro. Plant Cell, Tissue Organ Cult. 87: 285-295.

Schaller F, Schaller A and Stintzi A (2005) Biosynthesis and metabolism of jasmonates. J. Plant Growth Reg. 23: 179-199.

Shimasaki K, Shiraga T and Fukumoto Y (2003) Effect of methyl jasmonate on organogenesis in shoot cultures of epiphytic and terrestrial Cymbidium species. Env. Control Biol. 41(2): 179-182.

Takahashi K, Fujino K, Kikuta Y and Koda Y (1994) Expansion of potato cells in response to jasmonic acid. Plant Sci. 100: 3-8.

Teixeira da Silva JA (2012) New basal media for protocorm-like body and callus induction of hybrid Cymbidium. J Fruit Ornam Plant Res. 20(2):127-133.

Teixeira da Silva JA, Chan M-T, Sanjaya, Chai M-L and Tanaka M (2006a) Priming abiotic factors for optimal hybrid Cymbidium (Orchidaceae) PLB and callus induction, plantlet formation, and their subsequent cytogenetic stability analysis. Sci. Hortic. 109(4): 368-378.

Teixeira da Silva JA (2013) The role of thin cell layers in regeneration and transformation in orchids. Plant Cell Tiss. Org. Cult. (in press).

Teixeira da Silva JA, Singh N and Tanaka M (2006b) Priming biotic factors for optimal protocorm-like body and callus induction in hybrid Cymbidium (Orchidaceae), and assessment of cytogenetic stability in regenerated plantlets. Plant Cell, Tissue Organ Cult. 84: 119-128. 
Teixeira da Silva JA and Tanaka M (2006) Embryogenic callus, PLB and TCL paths to regeneration in hybrid Cymbidium (Orchidaceae). J. Plant Growth Reg. 25(3): 203-210.

Teixeira da Silva JA, Yam T, Fukai S, Nayak N and Tanaka M (2005) Establishment of optimum nutrient media for in vitro propagation of Cymbidium Sw. (Orchidaceae) using protocorm-like body segments. Prop. Orn. Plants 5(3): 129-136.

Toro FJ, Martín-Closas L and Pelacho AM (2003) Jasmonates promote cabbage (Brassica oleracea L. var. capitata L.) root and shoot development. Plant Soil 255: 77-83.

Ulloa RM, Raices M, MacIntosh GC, Maldonado S and Tellez-Inon MT (2002) Jasmonic acid affects plant morphology and calcium-dependent protein kinase expression and activity in Solanum tuberosum. Physiol. Plant. 115: 417-427.

Vacin E and Went FW (1949) Some pH changes in nutrient solutions. Bot. Gaz. 110: 605613. 